Article

\title{
Synthesis of Magnesium Nickel Boride Aggregates via Borohydride Autogenous Pressure
}

\author{
Mahboobeh Shahbazi *, Henrietta E. Cathey and Ian D. R. Mackinnon (iD \\ Institute for Future Environments and Science and Engineering Faculty, Queensland University of \\ Technology (QUT), Brisbane, QLD 4001, Australia; henrietta.cathey@qut.edu.au (H.E.C.); \\ ian.mackinnon@qut.edu.au (I.D.R.M.) \\ * Correspondence: Mahboobeh.shahbazi@qut.edu.au; Tel.: +61-432-531-829
}

Received: 2 March 2018; Accepted: 21 March 2018; Published: 23 March 2018

\begin{abstract}
We demonstrate synthesis of the ternary intermetallic $\mathrm{MgNi}_{3} \mathrm{~B}_{2}$ using autogenous pressure from the reaction of $\mathrm{NaBH}_{4}$ with $\mathrm{Mg}$ and $\mathrm{Ni}$ metal powder. The decomposition of $\mathrm{NaBH}_{4}$ to $\mathrm{H}_{2}$ and $\mathrm{B}_{2} \mathrm{H}_{6}$ commences at low temperatures in the presence of $\mathrm{Mg}$ and/or $\mathrm{Ni}$ and promotes formation of Ni-borides and $\mathrm{MgNi}_{3} \mathrm{~B}_{2}$ with the increase in temperature. $\mathrm{MgNi}_{3} \mathrm{~B}_{2}$ aggregates with Ni-boride cores are formed when the reaction temperature is $>670{ }^{\circ} \mathrm{C}$ and autogenous pressure is $>1.7 \mathrm{MPa}$. Morphologies and microstructures suggest that solid-gas and liquid-gas reactions are dominant mechanisms and that $\mathrm{Ni}$-borides form at a lower temperature than $\mathrm{MgNi}_{3} \mathrm{~B}_{2}$. Magnetic measurements of the core-shell $\mathrm{MgNi}_{3} \mathrm{~B}_{2}$ aggregates are consistent with ferromagnetic behaviour in contrast to stoichiometric $\mathrm{MgNi}_{3} \mathrm{~B}_{2}$ which is diamagnetic at room temperature.
\end{abstract}

Keywords: ternary metal borides; autogenous pressure synthesis; magnesium nickel boride; microstructures

\section{Introduction}

Metal hydrides and metal borides, in particular, $\mathrm{Mg}$-based compounds such as $\mathrm{MgH}_{2}, \mathrm{MgB}_{2}$, and ternary metal varieties that include $\mathrm{Ni}$, are attractive materials for a range of applications including hydrogen storage [1-3] as well as electron transport [4,5] and/or electron storage [6]. Metal borides are commonly produced using solid-state reactions with mixed elemental components in a reducing environment at relatively high temperatures $[7,8]$. Liquid phase methods have been explored for production of nano-scale borides $[9,10]$ but with increased complexity of processing due to the absence of a reactive elemental boron species that can decompose under conditions typical for nano-syntheses. In general, the intrinsic and strong covalent B-B and M-B bonding in boron-based solids [10] requires high temperature conditions to effect syntheses of metal borides.

Typical methods to produce $\mathrm{Mg}-\mathrm{Ni}-\mathrm{B}$ compounds include reacting borides or boron with metals under reducing conditions. For example, mechanical milling of $\mathrm{MgB}_{2}$ and $\mathrm{Ni}$ precursors followed by sintering at $975{ }^{\circ} \mathrm{C}$ with an inert atmosphere [11]; ball milling of $\mathrm{Mg}, \mathrm{Ni}$, and $\mathrm{B}$ powders with sintering at $800{ }^{\circ} \mathrm{C}$ [12]; or heating the elements in a sealed Ta container at $950{ }^{\circ} \mathrm{C}$ for seven days [5] results in formation of $\mathrm{Mg}-\mathrm{Ni}-\mathrm{B}$ compounds. In addition, a $\mathrm{Mg}-\mathrm{Ni}-\mathrm{B}$ compound occurs as a reaction layer (ranging from $10 \mu \mathrm{m}$ to $20 \mu \mathrm{m}$ thick) on $\mathrm{MgB}_{2}$ wires when fabricated with a Ni sheath [13]. The reaction layer forms by migration of $\mathrm{Ni}$ into the $\mathrm{MgB}_{2}$ core with heat treatments between $800{ }^{\circ} \mathrm{C}$ and $960{ }^{\circ} \mathrm{C}$ [12].

Prior to the definitive study by Manfrinetti et al. [5], reports on the composition and structure of the $\mathrm{Mg}-\mathrm{Ni}-\mathrm{B}$ phase synthesized under these conditions were inconsistent [14,15]. Proposed compositions ranged from $\mathrm{Mg}_{2} \mathrm{Ni}_{5} \mathrm{~B}_{4}$ to $\mathrm{MgNi}_{3} \mathrm{~B}_{2}$ and $\mathrm{MgNiB}$ [5]. Use of powder and single crystal diffraction techniques enabled clarification of the stoichiometry as $\mathrm{MgNi}_{3} \mathrm{~B}_{2}$ with the structure shown in Figure 1 . 
For $\mathrm{MgNi}_{3} \mathrm{~B}_{2}$, atoms are ordered on specific sites with $\mathrm{B}$ arranged around $\mathrm{Mg}$ in a distorted hexagon as shown in Figure 1a looking down the $c$ axis. Ni octahedral units are linked to B at both apical and equatorial sites of the Ni octahedra as shown in a perspective view in Figure $1 \mathrm{~b}$. In this structure, average B-B bond distances are $1.88 \AA$ [5], consistent with typical bond lengths observed in diborides [16].
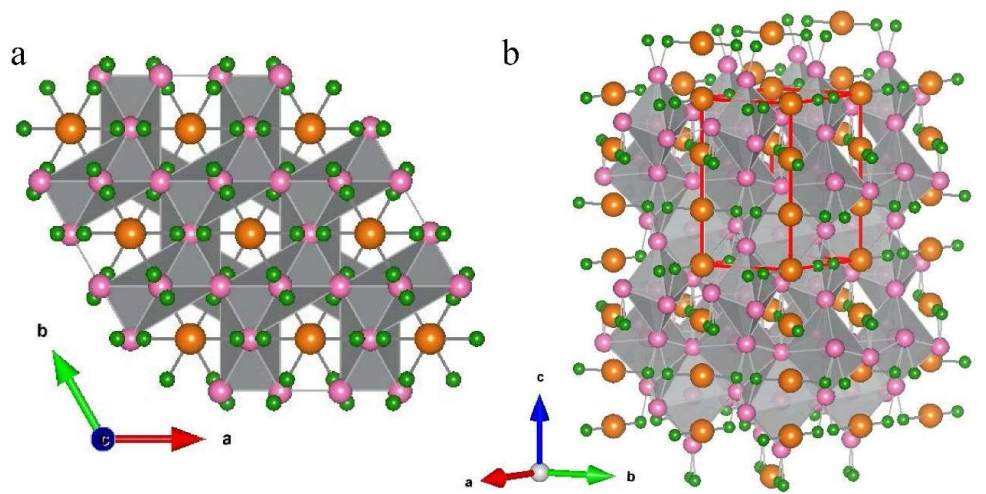

Figure 1. Crystal structure of $\mathrm{MgNi}_{3} \mathrm{~B}_{2}$ (a) along the $c$ axis highlighting the hexagonal array of $\mathrm{B}$ atoms in the $\mathrm{Mg}-\mathrm{B}$ plane and (b) perspective view showing B atoms linked at apical equatorial sites of the $\mathrm{Ni}$ octahedral. Unit cell is outlined in red. $\mathrm{Mg}$ atoms are orange, $\mathrm{B}$ atoms are green, and $\mathrm{Ni}$ atoms are pink.

Production of boron compounds at lower temperatures than currently used in solid state synthesis is motivated by the potential for facile production at sample sizes that may scale to industrial use. This strategy has been demonstrated for $\mathrm{MgB}_{2}$ and includes the use of metal borohydrides to generate reactive gaseous boron species $[17,18]$. In this work, we utilise a useful attribute of $\mathrm{NaBH}_{4}$ powder when subjected to heating in the presence of specific metals [19]. This attribute is low temperature decomposition to form $\mathrm{H}_{2}$ and higher borohydride analogues catalysed by the presence of $\mathrm{Mg}$ and Ni $[17,18]$. Using an instrumented Parr-type reactor, we delineate the conditions for formation of $\mathrm{MgNi}_{3} \mathrm{~B}_{2}$ and describe a possible mechanism for synthesis at temperatures above $670{ }^{\circ} \mathrm{C}$.

\section{Materials and Methods}

\subsection{Boride Synthesis}

Molar ratios of $\mathrm{Mg}$ powder ( $<50$ mesh size; $99.9 \%$ purity), $\mathrm{Ni}\left(<150 \mu \mathrm{m} ; 99.99 \%\right.$ purity), and $\mathrm{NaBH}_{4}$ powder (99.99\% purity) supplied by Sigma-Aldrich (Saint Louis, MO, USA) are weighed, ground in an agate mortar and placed into a $50 \mathrm{~mL}$ Parr reactor within a controlled atmosphere glove box containing Argon (99.99\% purity). The reactor is designed with an internal fixed head and cylinder of Inconel 601 steel with a graphite seal to accommodate a maximum pressure of $20 \mathrm{MPa}$ and a maximum average temperature of $725^{\circ} \mathrm{C}$ at the base of the reactor. Prior to use, the reactor is thoroughly washed with water and dried in a vacuum oven up to $120^{\circ} \mathrm{C}$ overnight. For some experiments, a boron nitride sleeve is introduced into the reactor to minimise reaction with the Ni-rich side-walls of the reactor.

The starting materials are added to the reactor, sealed tightly, and removed from the glove box. The reaction chamber is heated according to a standard protocol via thermocouple controller. The change in pressure is monitored during the reaction using a dial pressure gauge and an Ashcroft transducer mounted atop the reaction chamber. The temperature sensor is centred within the reactor and both temperature and pressure are recorded every minute. The temperature sensor is not embedded within the precursor materials which, at the start of synthesis, are located at the bottom of the chamber.

The reactor design results in a thermal gradient between the bottom and top of the reactor during ramp up to the equilibration temperature. This gradient depends on the operating temperature recorded at the thermocouple and location within the reactor. For example, at a thermocouple reading 
of $500{ }^{\circ} \mathrm{C}$ at the centre of the reactor, the difference in temperature at the top or bottom of the reactor could be up to $\pm 225^{\circ} \mathrm{C}$. The thermocouple measurements record average temperatures within the reactor and, as shown in Figure 2a, indicate progress of the reaction over time. This record provides an indirect measure of reaction stability (e.g., at equilibria; endothermic, exothermic) within a closed environment. An advantage of this reactor design is that gaseous phases such as sodium and sodium hydride condense at the cooler top of the reactor [18]. On cooling the reaction chamber to room temperature, the reactor is opened in the argon-filled glove box via slow pressure equilibration using a gas release valve.

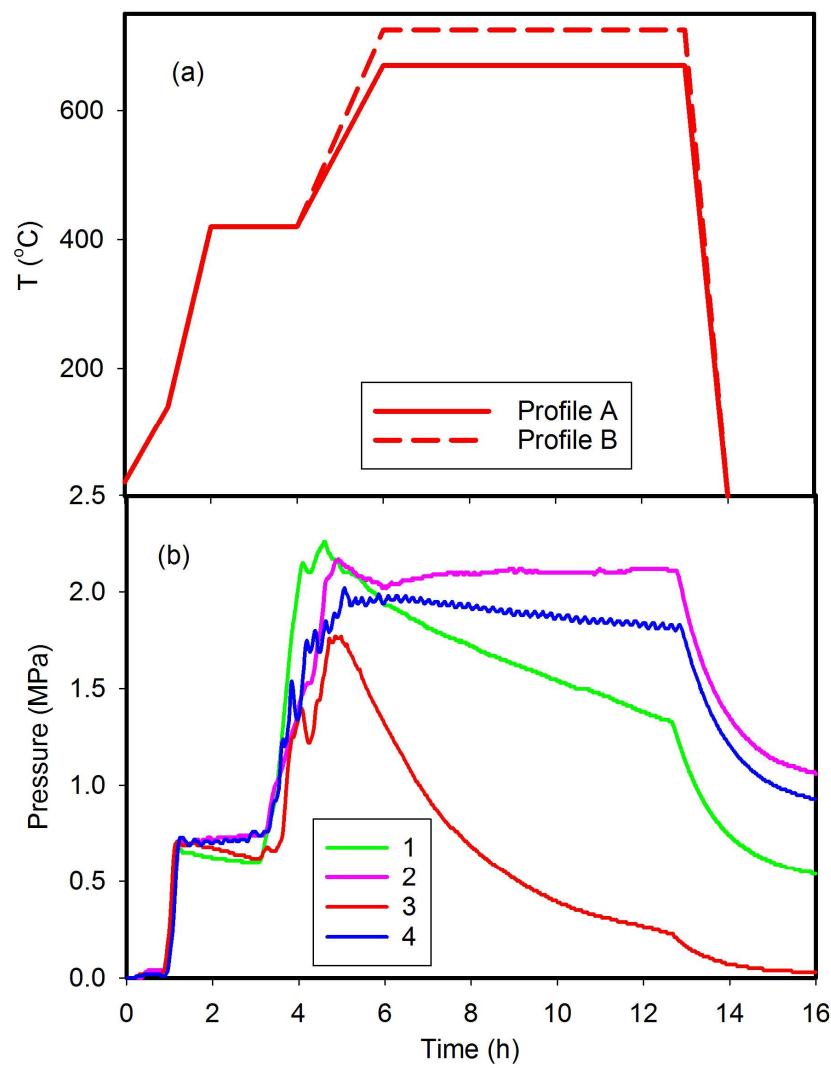

Figure 2. (a) Typical heating profile and (b) pressure profiles for synthesis of $\mathrm{MgNi}_{3} \mathrm{~B}_{2}$ and other $\mathrm{Ni}-\mathrm{B}$ phases with conditions as listed in Table 1.

A consistent heating rate of $10{ }^{\circ} \mathrm{C} / \mathrm{min}$ is used in all reactions albeit at different temperatures, the heating rate is held constant for varying periods of time. In general, the reactor heating rate is held constant at selected base temperatures of: (i) $\sim 140{ }^{\circ} \mathrm{C}$; (ii) $420{ }^{\circ} \mathrm{C}$; and (iii) $670{ }^{\circ} \mathrm{C}$ or $725{ }^{\circ} \mathrm{C}$ for variable periods of time. These specific heating rates and constant temperature periods are identified in Table 1 , noting that $\mathrm{T}_{\max }$ values are estimated for the base of the reactor.

Table 1. Synthesis conditions * for $\mathrm{MgNi}_{3} \mathrm{~B}_{2}$.

\begin{tabular}{ccccccc}
\hline Run No. & $\mathbf{N a B H}_{\mathbf{4}}(\mathbf{g})$ & $\mathbf{T}_{\mathbf{m a x}}{ }^{\boldsymbol{f}}\left({ }^{\circ} \mathbf{C}\right)$ & $\mathbf{t}_{\mathbf{T m}}(\mathbf{h})$ & $\mathbf{P}_{\mathbf{m a x}} \mathbf{M P a}$ & $\mathbf{\%} \mathbf{M g N i}_{3} \mathbf{B}_{\mathbf{2}}$ & Other Phases ** \\
\hline 1 & 0.76 & 725 & 8 & 2.2 & $88 \%$ & $\mathrm{MgNi}_{6.7} \mathrm{~B}_{2} \mathrm{MgNi}_{7} \mathrm{~B}_{3}$ \\
2 & 0.76 & 670 & 8 & 2.1 & $70 \%$ & $\mathrm{MgNi}_{6.7} \mathrm{~B}_{2} \mathrm{MgNi}_{7} \mathrm{~B}_{3} \mathrm{Ni}_{2} \mathrm{~B} \mathrm{Ni}{ }_{3} \mathrm{~B}$ \\
3 & 0.72 & 670 & 8 & 1.7 & $76 \%$ & $\mathrm{MgNi}_{6.7} \mathrm{~B}_{2} \mathrm{MgNi}_{7} \mathrm{~B}_{3} \mathrm{Ni}_{2} \mathrm{~B} \mathrm{Ni}_{3} \mathrm{~B}$ \\
4 & 0.72 & 670 & 8 & 2.0 & $90 \%$ & $\mathrm{MgNi}_{6.7} \mathrm{~B}_{2} \mathrm{Ni}_{2} \mathrm{~B} \mathrm{MgNi}_{7} \mathrm{~B}_{3}$ \\
5 & 0.72 & 670 & 40 & 2.0 & $85 \%$ & $\mathrm{MgNi}_{6.7} \mathrm{~B}_{2} \mathrm{MgNi}_{7} \mathrm{~B}_{3} \mathrm{Ni}_{3} \mathrm{~B}$ \\
6 & 0.72 & 725 & 30 & 2.5 & $76 \%$ & $\mathrm{Ni}_{2} \mathrm{~B}(12 \%) \mathrm{MgNi}_{7} \mathrm{~B}_{3}(11 \%)$ \\
\hline
\end{tabular}

${ }^{*}$ Molar ratio of Mg:Ni is 1:3 for all reactions; ${ }^{* *}$ other phases are generally less than $10 \%$ by Rietveld refinement except where noted in parentheses. $\mathrm{t}_{\mathrm{Tm}}$ is the time the reactor is held at $\mathrm{T}_{\max } ;{ }^{£}$ Base temperature. 


\subsection{Characterisation}

Polycrystalline samples are characterized using X-ray powder diffraction and electron microscopy equipped with microanalysis. X-ray powder diffraction patterns are obtained using either $\mathrm{Cu} K \alpha 1$ or Co K $\alpha 1$ radiation in Bragg Brentano geometry with $0.02^{\circ} 2 \theta$ steps and a counting time of $10 \mathrm{~s}$ per step using PANalytical X-ray diffractometers. Diffraction patterns are refined and indexed using the software program Topas (Florence, KY, USA) [20]. X-ray diffraction patterns and electron microscopy indicate that all synthesised samples are multiphase with $\mathrm{MgNi}_{3} \mathrm{~B}_{2}$ as a predominant phase. Samples with high proportions of $\mathrm{MgNi}_{3} \mathrm{~B}_{2}$ (i.e., $>80 \%$ ) were selected for additional data collection using a PANalytical X-ray diffractometer (Almelo, The Netherlands) for subsequent Rietveld refinement using Topas. Schematic models of crystal structures shown in Figure 1 are built using data from Manfrinetti et al. [5] as input to the program VESTA [21].

Gases generated during reactions are collected for analysis at selected thermocouple temperatures of $65{ }^{\circ} \mathrm{C}$ and $120^{\circ} \mathrm{C}$ using a Hamilton gas-tight syringe. These temperatures are correlated to base temperature of $120^{\circ} \mathrm{C}$ and $200^{\circ} \mathrm{C}$, respectively. These gases are characterised using a Sercon 20-22 isotope mass spectrometer coupled with a GSL elemental analyser unit standardised to Ar and He. Additional gas analyses standardised for $\mathrm{CO}_{2}, \mathrm{CH}_{4}$ and $\mathrm{N}_{2} \mathrm{O}$ are undertaken with a Maestro MPS Headspace (Linthicum, MD, USA) and Agilent 7890A Gas Chromatograph (Santa Clara, CA, USA).

A Zeiss Sigma Field Emission SEM (Carl Zeiss Pty Ltd., North Ryde, Australia) equipped with an Oxford Instruments SDD detector (Abington, UK) is used for microscopy observations and energy dispersive spectroscopy (EDS) analysis. Samples are prepared for SEM/EDS by placing a thin layer of powder onto aluminium stubs with double-sided carbon tape. In general, samples are not coated with a conductive coating to avoid analytical interference(s). Elemental analysis is carried out at an accelerating voltage of $15 \mathrm{kV}$ at $8.5 \mathrm{~mm}$ working distance. Excessively charging samples are imaged at lower accelerating voltages of $5 \mathrm{kV}$ or $10 \mathrm{kV}$.

Quantitative elemental analyses are performed using a JEOL JXA 8530F field emission electron probe microanalyzer (FE-EPMA, JEOL, Tokyo, Japan) equipped with five wavelength-dispersive spectrometers (WDS) and using Probe for EPMA software (Eugene, OR, USA). For these analyses, powder samples are mixed with conductive resin and placed in a $30 \mathrm{~mm}$ diameter mould inside a hot mounting press. The sample mount is polished with a series of diamond pads and cloths to a mirror finish suited to electron microprobe analysis. Spot analyses on borides are performed using the following combined conditions: $\mathrm{B}$ and $\mathrm{Mg} \mathrm{K} \alpha \mathrm{X}$-ray intensities are measured simultaneously at $7 \mathrm{kV}$ accelerating voltage, followed immediately by intensity measurement of the $\mathrm{Ni} \mathrm{K} \alpha \mathrm{X}$-ray line at $15 \mathrm{kV}$ accelerating voltage. A focused beam is utilized and beam current maintained at $40 \mathrm{nA}$ under both conditions.

For EPMA data reduction, the PROZA $\varphi(\rho z)$ matrix correction method of Bastin [22,23] is employed along with the MACJTA database of mass absorption coefficients. B K $\alpha$ radiation is measured using an LDEB analyzing crystal $(2 \mathrm{~d} \sim 15 \mathrm{~nm})$ and an open detector slit (GFPC), while TAP and LIF analyzing crystals are used for $\mathrm{Mg}$ and $\mathrm{Ni}$, respectively. An anti-contamination cold finger cooled by liquid nitrogen is used during all acquisitions. Standards include $\mathrm{MgO}, \mathrm{Ni}_{90} \mathrm{Fe}_{10}$ alloy, and in-house $\mathrm{MgB}_{2}$. To avoid analytical errors associated with peak shift and peak shape changes for boron, the integrated intensity method for acquisition of full peak intensity is used in the Probe for $E P M A$ software. The scan length for the boron peak corresponds to an energy range from $\sim 160 \mathrm{eV}$ to $270 \mathrm{eV}$ with a counting time of $180 \mathrm{~s}$ for the integrated intensity measurement, followed by $60 \mathrm{~s}$ for background positions either side of the peak. An exponential fit to the background positions is used to model the background intensity under the peak. On and off-peak count times are $10 \mathrm{~s}$ for Ni and $20 \mathrm{~s}$ for Mg. Accompanying elemental X-ray maps of individual powder particles by WDS on the electron microprobe are conducted at $7 \mathrm{kV}$ accelerating voltage, $40 \mathrm{nA}$ beam current, and $20 \mathrm{~ms}$ dwell time in beam scanning mode.

In this study, the beam produced by a $7 \mathrm{kV}$ and fully focused $40 \mathrm{nA}$ source is chosen to reduce the electron beam-specimen interaction volume to $<1 \mu \mathrm{m}$ for boron and magnesium. The detection 
limits under the combined conditions are $0.16 \mathrm{wt} \%$ for B, $0.02 \mathrm{wt} \%$ for $\mathrm{Mg}$, and $0.04 \mathrm{wt} \%$ for $\mathrm{Ni}$. The average analytical error for boron for individual spot analyses is $8.7 \%$. A statistical program is used to determine the envelope for production of characteristic X-rays using the EPMA under these operating conditions. At $7 \mathrm{kV}$ the lateral and vertical spatial resolution for excitation of the $\mathrm{K} \alpha \mathrm{X}$-ray lines of $\mathrm{B}$ and $\mathrm{Mg}$ is $<1 \mu \mathrm{m}$, as is that of the $\mathrm{Ni} \mathrm{K} \alpha$ X-ray line at $15 \mathrm{kV}$ as calculated using the CASINO Monte Carlo modeling program [24] for electron trajectories (Figure 3).

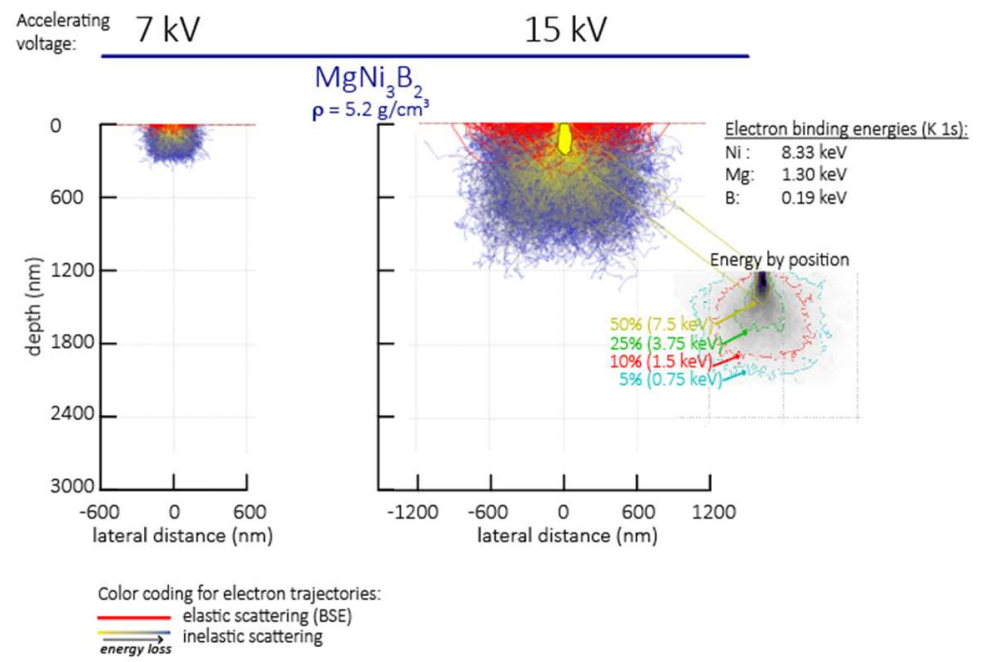

Figure 3. Electron beam-specimen interaction volumes for EPMA analyses at $7 \mathrm{kV}$ and $15 \mathrm{kV}$ accelerating voltage. The inset at right ("energy by position") illustrates the amount of energy lost by the simulated electron trajectories as a function of depth and lateral distance. For example the Ni K $\alpha$ $\mathrm{X}$-ray line (K 1s binding energy $8.33 \mathrm{KeV}$ ) cannot be excited at depths greater than $\sim 300 \mathrm{~nm}$, whereas the excitation volume for $\mathrm{B} K \alpha(\mathrm{K} 1 \mathrm{~s}$ binding energy $0.19 \mathrm{keV})$ extends near the outermost limits of electron trajectories, exceeding $1 \mu \mathrm{m}^{3}$ at $15 \mathrm{kV}$ but confined to $<<1 \mu \mathrm{m}^{3}$ at $7 \mathrm{kV}$ accelerating voltage.

DC magnetization measurements are performed using a Cryogenics Ltd. Mini cryogen-free $5 \mathrm{~T}$ system (London, UK). Magnetization field isothermal loop is determined within $\pm 5 \mathrm{~T}$ at $290 \mathrm{~K}$.

\section{Results}

In general, data presented in this work are a summary of more than twenty-five separate experiments, including repeat syntheses, across a range of temperature and pressure conditions. Previous syntheses using metal borohydrides $[17,18]$ have been used to guide the synthesis strategy for optimum production of $\mathrm{MgNi}_{3} \mathrm{~B}_{2}$.

\subsection{Synthesis}

Figure 2a shows typical heating profiles that result in synthesis of $\mathrm{MgNi}_{3} \mathrm{~B}_{2}$ using the $50 \mathrm{~mL}$ reactor including a heating profile for Run 1 listed in Table 1. The pressure profiles for reactions in Runs 1-4, which are most representative of this compositional suite, are shown in Figure $2 \mathrm{~b}$. In all reactions, pressure increases to a maximum value $\left(\mathrm{P}_{\max }\right)$ ranging between $1.7 \mathrm{MPa}$ and $2.5 \mathrm{MPa}$ when the reactor is at the maximum temperature $\left(\mathrm{T}_{\max }\right)$. The rate of pressure decrease after $\mathrm{P}_{\max }$ is achieved varies for each reaction listed in Table 1 , and is dependent on a number of variables including the ratio of starting materials within the reactor.

In all cases, $\mathrm{MgNi}_{3} \mathrm{~B}_{2}$ is the major phase based on X-ray diffraction data and Rietveld refinement using Topas software. An excess of $\mathrm{NaBH}_{4}$ in the starting mixture results in a higher percentage of $\mathrm{Ni}-\mathrm{B}$ phases and a lower percentage of $\mathrm{MgNi}_{3} \mathrm{~B}_{2}$ (see Table 1). Table 1 describes generic variables that affect the relative proportions of $\mathrm{MgNi}_{3} \mathrm{~B}_{2}$ product. For example, a higher $\mathrm{T}_{\max }$ value of $725^{\circ} \mathrm{C}$ at the base results in a higher yield of $\mathrm{MgNi}_{3} \mathrm{~B}_{2}$ for the same molar ratio of starting materials and 
similar levels of autogenous pressure (i.e., Run numbers 1 and 2). Similarly, for $\mathrm{T}_{\max }=670{ }^{\circ} \mathrm{C}$, a higher autogenous pressure may also result in a higher yield of $\mathrm{MgNi}_{3} \mathrm{~B}_{2}$ (i.e., Runs 3 and 4). In general, the optimum base temperature and pressure range for highest yield of $\mathrm{MgNi}_{3} \mathrm{~B}_{2}$ is between $670{ }^{\circ} \mathrm{C}-725$ ${ }^{\circ} \mathrm{C}$ and 2.0 MPa-2.2 MPa.

\subsection{Structure Determination}

Powder diffraction patterns from selected samples listed in Table 1 are re-collected at a higher resolution using $\mathrm{Cu} \mathrm{K} \alpha$ radiation for counting times suited to Rietveld refinement using TOPAS. Structural data from Manfrinetti et al. [5] are used as input to refinement of XRD data for these samples. Table 2 shows refined data for $\mathrm{MgNi}_{3} \mathrm{~B}_{2}$ from this study compared with that by Manfrinetti et al. [5] based on data collected from a single crystal. Refined lattice parameters on the $\mathrm{MgNi}_{3} \mathrm{~B}_{2} \mathrm{Phase}$ from this study are in good agreement with results reported by Manfrinetti et al. [5]. The resulting diffraction profile after Rietveld refinement of the Run 1 sample is shown in Figure 4. Phase analysis of this diffraction data also shows minor presence of other compounds including $\mathrm{MgNi}_{6.7} \mathrm{~B}_{2}(7 \%)$ and $\mathrm{MgNi}_{7} \mathrm{~B}_{3},(2 \%)$ with lower amounts of Ni-B phases.

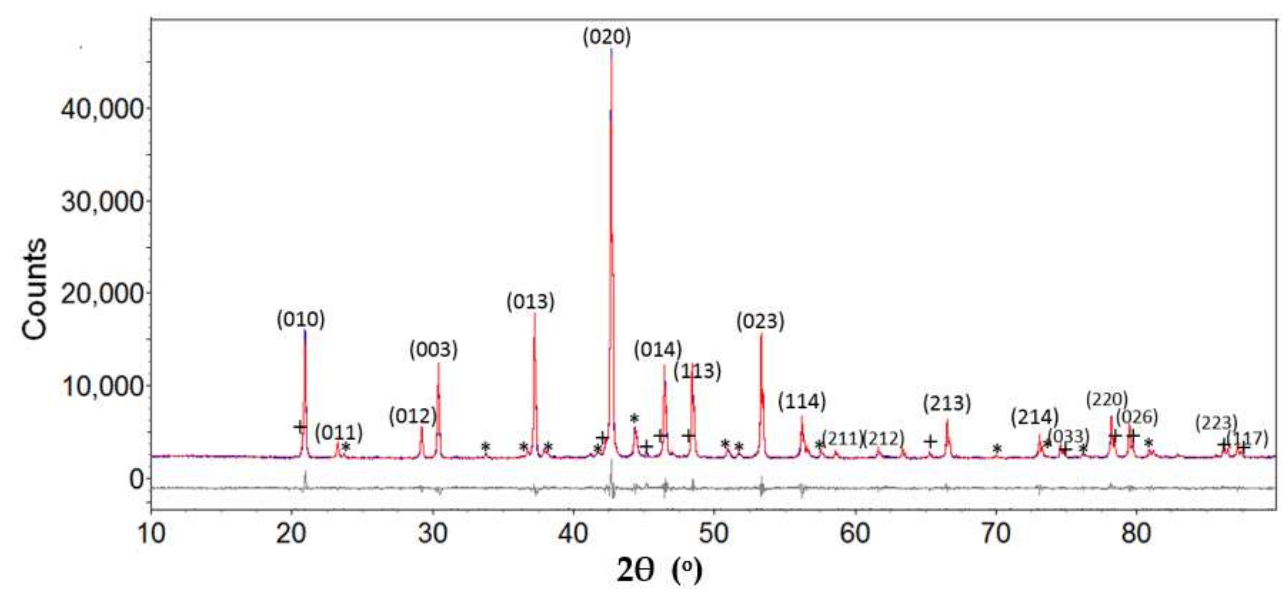

Figure 4. The experimental (blue), fitted (red), and difference (grey line below observed and calculated pattern) XRD profile for sample from Run 1. Indexed reflections are for $\mathrm{MgNi}_{3} \mathrm{~B}_{2}$. Other phases including $\mathrm{MgNi}_{6.7} \mathrm{~B}_{2}$ and $\mathrm{MgNi}_{7} \mathrm{~B}_{3}$ denoted with * and +, respectively.

Table 2. Results of refinement for $\mathrm{MgNi}_{3} \mathrm{~B}_{2}$ from Run 1 .

\begin{tabular}{ccc}
\hline Parameter & $\mathbf{M g N i}_{3} \mathbf{B}_{2}$ (This Work) & $\mathbf{M g N i}_{3} \mathbf{B}_{2}$ [5] (Single Crystal) \\
\hline Space group & $\mathrm{P}_{4} 22$ & $\mathrm{P} 6_{4} 22$ \\
$\mathrm{a}(\AA)$ & $4.8799(1)$ & $4.8800(1)$ \\
$\mathrm{c}(\AA)$ & $8.7884(2)$ & $8.7870(1)$ \\
Cell volume $\left(\AA^{3}\right)$ & $181.2(1)$ & 181.22 \\
$\mathrm{R}_{\mathrm{wp}}$ & $3.8 \%$ & $4.0 \%$ \\
$\mathrm{R}_{\mathrm{p}}$ & $2.7 \%$ & $1.9 \%$ \\
$\mathrm{GoF}$ & 1.98 & 0.93 \\
Atom: $\mathrm{Ni}_{2}(\mathrm{z} ; 6 \mathrm{f})$ & $0.2062(1)$ & $0.2083(1)$ \\
Atom: $\mathrm{B}(\mathrm{x} ; 6 \mathrm{i})$ & $0.6102(7)$ & $0.6110(8)$ \\
\hline
\end{tabular}

\subsection{Morphology and Microstructure}

Representative SEM images of $\mathrm{MgNi}_{3} \mathrm{~B}_{2}$ powder obtained from Run 1 are shown in Figure 5. Two different morphologies - one resembling a flower and the other a cauliflower-are common forms in all samples examined from these syntheses. Close observation of individual morphologies in Figure 5 reveals that a single flower comprises hexagonal rod-like crystals $<200 \mathrm{~nm}$ diameter with lengths ranging between $1 \mu \mathrm{m}$ and $2 \mu \mathrm{m}$. The inset shows a higher magnification image of the cauliflower-shaped 
$\mathrm{MgNi}_{3} \mathrm{~B}_{2}$ morphology. Smooth, rounded particles with sizes varying from $50 \mathrm{~nm}$ up to several hundred $\mathrm{nm}$ form micron-sized agglomerates as shown in Figure 5a (inset). Figure 5c,d are SEM images of as-prepared powder from Run 5 with aggregates of nanometre sized particles arranged as hollow $\mathrm{Mg}-\mathrm{Ni}-\mathrm{B}$ shells or as remnant broken outlines of partially spherical shells without Ni-B cores.
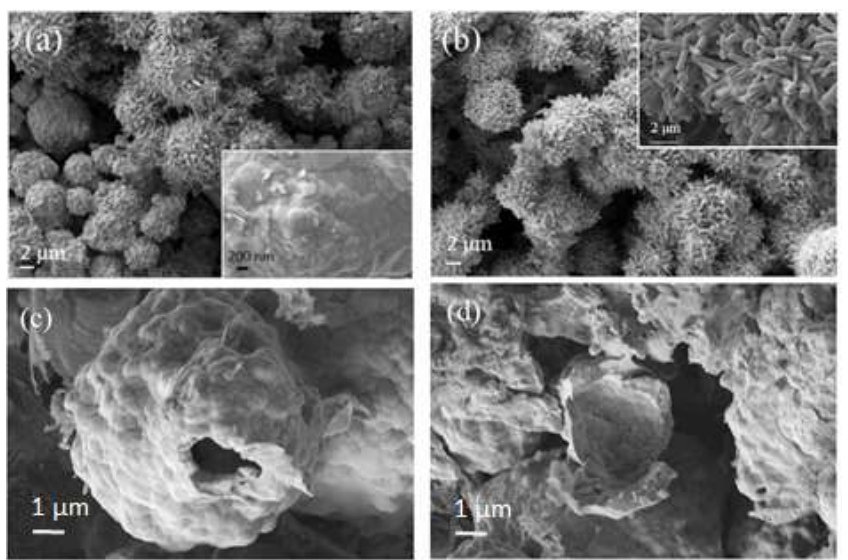

Figure 5. SEM images of $\mathrm{MgNi}_{3} \mathrm{~B}_{2}$ powder produced by autogenous pressure reactions listed in Table 1. Higher resolution SEM images (inset) show: (a) cauliflower shaped morphology consisting of smoothly rounded crystals, (b) hexagonal rod-like crystals of flower-like morphology. (c,d) SEM images of as-prepared powder from Run 5 showing a Mg-Ni-B shell and partial, or broken, shells without a Ni-B core.

A polished section of $\mathrm{MgNi}_{3} \mathrm{~B}_{2}$ grains produced from Run 3 is shown in Figure 6. The SEM image shows a $\sim 15 \mu \mathrm{m} \times \sim 10 \mu \mathrm{m}$ aggregate with different image contrast between the core and outer regions (Figure $6 \mathrm{a}$ ). Figure $6 \mathrm{~b}, \mathrm{c}$ show the distribution of $\mathrm{Ni}$ and $\mathrm{Mg}$ within this aggregate using $\mathrm{X}$-ray mapping. $\mathrm{Ni}$ is evenly distributed within the aggregate but it is clear that $\mathrm{Mg}$ is concentrated in the outer rim (Figure 6c). For this particular analysis using the FeSEM, the total collection time to acquire a boron signal with sufficient statistical certainty is $>10 \mathrm{~h}$ which, with stage drift, precludes superposition of the boron distribution on these images.
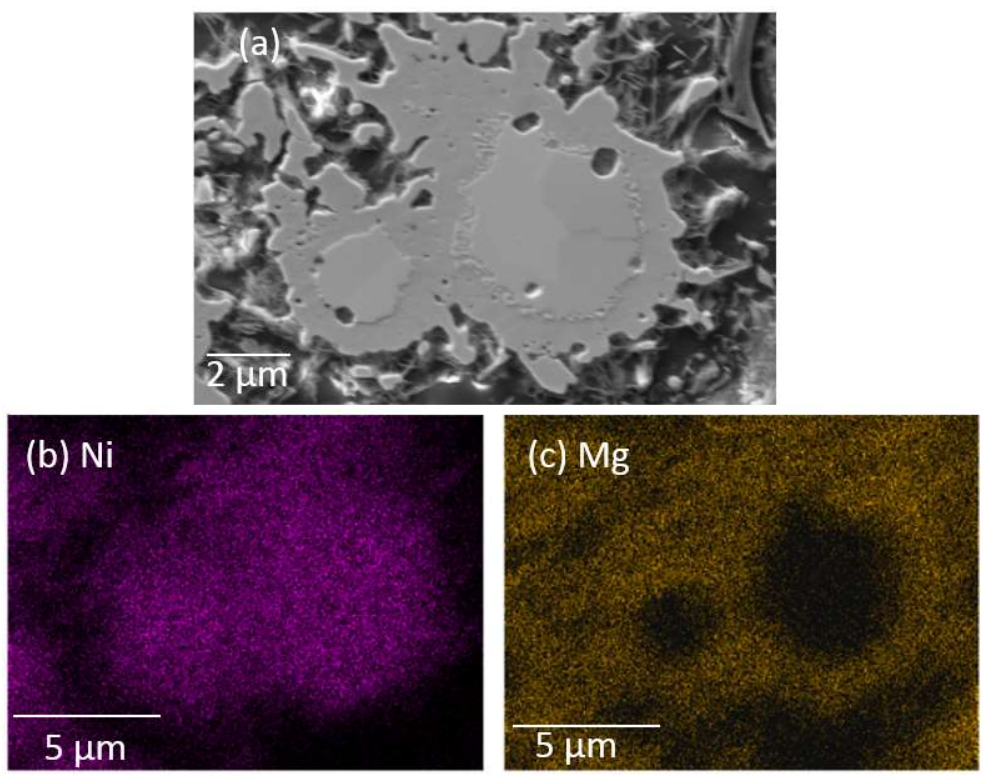

Figure 6. (a) Secondary electron image and elemental map using the FE-SEM for (b) $\mathrm{Ni}$ and (c) $\mathrm{Mg}$ of a polished sample from Run 3 . 
A more precise method that also allows a high signal to noise ratio for low atomic number elemental X-ray mapping is EPMA. This method also enables quantitative spot analyses with a spatial resolution of $1 \mu \mathrm{m}$ or less (see Section 2.2) of polished samples. In this work, we selected $\mathrm{Mg}$, $\mathrm{Ni}$, and $\mathrm{B}$ for analysis using WDS. An example of X-ray mapping by WDS for an aggregate from Run 5 is shown in Figure 7. Figure 7a is a backscattered electron image of the aggregate with accompanying element distributions for $\mathrm{Mg}, \mathrm{Ni}$, and $\mathrm{B}$ in Figure $7 \mathrm{~b}-\mathrm{d}$. The backscattered electron image shows a wide variation in image contrast typically ascribed to variations in relative mean atomic number. In general, lighter regions in a backscattered electron image are higher in atomic number than darker regions [25].

The X-ray maps and detailed line scans in Figure $7 \mathrm{~b}-\mathrm{d}$ show that $\mathrm{Ni}$ and $\mathrm{B}$ are concentrated in the centre, or core, of the aggregate while all three elements are present in the outer margins. Mg is absent in the core of this aggregate. The map and line scan in Figure $7 \mathrm{~d}$ show an increase in relative $\mathrm{B}$ concentration in the Ni-rich core region. This microstructure, that is, a core of Ni-B and an outer margin of $\mathrm{Mg}-\mathrm{Ni}-\mathrm{B}$, is a common attribute of grains analysed from each of the syntheses listed in Table 1. Close inspection of Figure 7a also indicates a nuanced variation in image contrast within the outer margin of the aggregate. This characteristic is due to variations in orientation of the individual $\mathrm{MgNi}_{3} \mathrm{~B}_{2}$ crystals that comprise the aggregate.

Figure 8 is a backscattered electron image of an aggregate from Run 3 (Table 1) showing a lighter core region and an outer, darker margin as well as locations of spot analyses using the EPMA. Again, the lighter region shows high levels of $\mathrm{Ni}$ and $\mathrm{B}$ and minimal or no $\mathrm{Mg}$. Variations in crystal orientation are discernible in the Mg-rich outer margins of this aggregate from Run 3.

Table 3 provides average compositions measured by electron microprobe of selected spots in different aggregates from Runs 3 and 5. The number of point analyses for designated regions of the aggregates are listed in Table 3. These data show that the concentration of $\mathrm{Mg}$ in many core regions of aggregates is below detection under the given conditions. Nevertheless, the concentration of boron ranges between $5.53 \mathrm{wt} \%$ and $12.2 \mathrm{wt} \%$, and the concentration of nickel between $87.2 \mathrm{wt} \%$ and $93.5 \mathrm{wt} \%$ in the cores of aggregates.
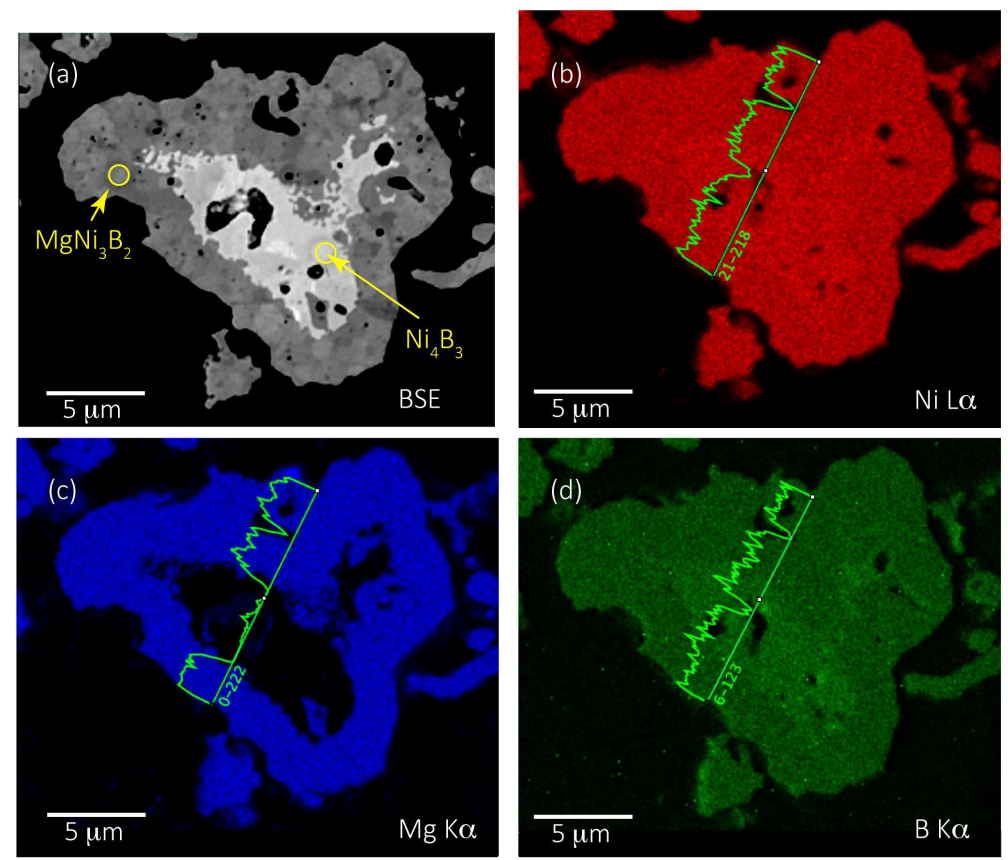

Figure 7. Aggregate from Run 5 showing (a) backscattered electron (BSE) image with image contrast corresponding to lighter $\mathrm{Ni}-\mathrm{B}$ and darker $\mathrm{Mg}-\mathrm{Ni}-\mathrm{B}$ regions; and wavelength-dispersive spectrometers (WDS) X-ray maps of (b) $\mathrm{Ni}$, (c) Mg and (d) B distribution in the aggregate. 


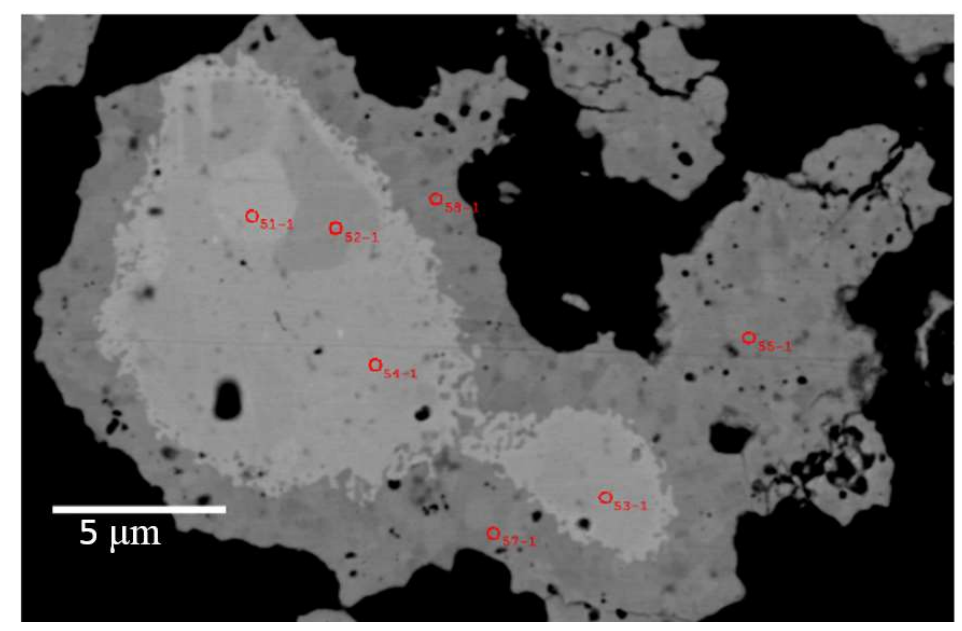

Figure 8. Backscattered electron image of an aggregate from Run 3 showing a bright core and darker outer margin corresponding to $\mathrm{Ni}-\mathrm{B}$ rich and $\mathrm{Mg}-\mathrm{Ni}-\mathrm{B}$ rich phases, respectively. Red circles denote locations of spot analyses using the field emission electron probe microanalyzer (EPMA); average values for these spot analyses are listed in Table 3.

As shown in Table 3 , the stoichiometry of Ni-B phases within the core regions includes $\mathrm{Ni}_{2} \mathrm{~B}, \mathrm{Ni}_{3} \mathrm{~B}$, and less commonly $\mathrm{Ni}_{4} \mathrm{~B}_{3}$. In the outer margin, or shell regions of these aggregates, the concentration of magnesium, nickel, and boron is $\sim 11.5 \mathrm{wt} \%, \sim 79 \mathrm{wt} \%$, and $9 \mathrm{wt} \%$, respectively. The stoichiometry of this outer margin is $\mathrm{MgNi}_{3} \mathrm{~B}_{2}$, consistent with X-ray diffraction data. In Run 5, aggregates show a core region with some Mg content (Table 3; Run 5, "core 1"). The consistency of analyses, judged not only by the total element weight percent but also by the low standard deviations per element, suggests that this composition, $\mathrm{MgNi}_{10.5} \mathrm{~B}_{3}$, may be an additional phase within the $\mathrm{Mg}-\mathrm{Ni}-\mathrm{B}$ compositional suite.

Table 3. Average compositions * $( \pm 1 \sigma)$ of selected regions in aggregates from Runs 3 and 5.

\begin{tabular}{|c|c|c|c|c|c|c|c|c|c|}
\hline \multirow[b]{2}{*}{ Compound } & \multirow[b]{2}{*}{$\mathbf{n}^{+}$} & \multicolumn{4}{|c|}{ Element (wt \%) } & \multicolumn{4}{|c|}{ Stoichiometry } \\
\hline & & B & Mg & $\mathbf{N i}$ & Total & B & $\mathrm{Mg}$ & $\mathbf{N i}$ & Total \\
\hline \multicolumn{10}{|l|}{ Run 3} \\
\hline $\begin{array}{l}\mathrm{Ni}_{2} \mathrm{~B} \\
\text { (core } 1 \text { ) }\end{array}$ & 4 & $\begin{array}{l}8.36 \\
(0.47)\end{array}$ & $\begin{array}{l}0.04 \\
(0.01)\end{array}$ & $\begin{array}{l}89.8 \\
(0.9)\end{array}$ & $\begin{array}{l}98.2 \\
(1.3)\end{array}$ & 1 & $\begin{array}{c}0.00 \\
(0.00)\end{array}$ & $\begin{array}{l}1.98 \\
(0.10)\end{array}$ & $\begin{array}{c}2.98 \\
(0.10)\end{array}$ \\
\hline $\begin{array}{l}\mathrm{Ni}_{3} \mathrm{~B} \\
\text { (core 2) }\end{array}$ & 5 & $\begin{array}{l}5.58 \\
(0.32)\end{array}$ & $\begin{array}{l}0.03 \\
(0.01)\end{array}$ & $\begin{array}{l}93.5 \\
(1.3)\end{array}$ & $\begin{array}{l}99.1 \\
(1.5)\end{array}$ & 1 & $\begin{array}{c}0.00 \\
(0.00)\end{array}$ & $\begin{array}{l}3.09 \\
(0.17)\end{array}$ & $\begin{array}{r}4.09 \\
(0.17)\end{array}$ \\
\hline $\begin{array}{c}\mathrm{Ni}_{4} \mathrm{~B}_{3} \\
\text { (mid-core) }\end{array}$ & 5 & $\begin{array}{l}12.0 \\
(0.1)\end{array}$ & $\begin{array}{l}0.04 \\
(0.02)\end{array}$ & $\begin{array}{l}87.9 \\
(0.5)\end{array}$ & $\begin{array}{l}99.9 \\
(0.4)\end{array}$ & 3 & $\begin{array}{c}0.00 \\
(0.00)\end{array}$ & $\begin{array}{l}4.06 \\
(0.06)\end{array}$ & $\begin{array}{c}7.06 \\
(0.06)\end{array}$ \\
\hline $\begin{array}{l}\mathrm{MgNi}_{3} \mathrm{~B}_{2} \\
\text { (shell) }\end{array}$ & 5 & $\begin{array}{l}9.01 \\
(0.34)\end{array}$ & $\begin{array}{l}11.5 \\
(0.1)\end{array}$ & $\begin{array}{l}79.2 \\
(1.4)\end{array}$ & $\begin{array}{l}99.6 \\
(1.3)\end{array}$ & 2 & $\begin{array}{c}1.13 \\
(0.05)\end{array}$ & $\begin{array}{l}3.24 \\
(0.16)\end{array}$ & $\begin{array}{c}6.37 \\
(0.21)\end{array}$ \\
\hline \multicolumn{10}{|l|}{ Run 5} \\
\hline $\begin{array}{c}\mathrm{MgNi}_{10.5} \mathrm{~B}_{3} \\
\text { (core1) }\end{array}$ & 3 & $\begin{array}{l}4.76 \\
(0.11)\end{array}$ & $\begin{array}{l}3.65 \\
(0.37)\end{array}$ & $\begin{array}{l}90.2 \\
(0.4)\end{array}$ & $\begin{array}{l}98.6 \\
(0.1)\end{array}$ & 3 & $\begin{array}{c}1.02 \\
(0.04)\end{array}$ & $\begin{array}{l}10.50 \\
(0.09)\end{array}$ & $\begin{array}{l}14.52 \\
(0.10)\end{array}$ \\
\hline $\begin{array}{c}\mathrm{Ni}_{3} \mathrm{~B} \\
\text { (core2) }\end{array}$ & 2 & 5.53 & bdl & 93.2 & 98.7 & 1 & bdl ** & 3.11 & 4.11 \\
\hline $\begin{array}{c}\mathrm{Ni}_{4} \mathrm{~B}_{3} \\
\text { (mid-core) }\end{array}$ & 1 & 12.2 & bdl & 87.2 & 99.5 & 3 & bdl ** & 3.94 & 6.94 \\
\hline $\begin{array}{c}\mathrm{MgNi}_{3} \mathrm{~B}_{2} \\
\text { (shell) }\end{array}$ & 8 & $\begin{array}{l}9.27 \\
(0.14)\end{array}$ & $\begin{array}{l}11.7 \\
(0.1)\end{array}$ & $\begin{array}{l}78.1 \\
(1.0)\end{array}$ & $\begin{array}{l}99.1 \\
(0.9)\end{array}$ & 2 & $\begin{array}{c}1.12 \\
(0.02)\end{array}$ & $\begin{array}{l}3.10 \\
(0.07)\end{array}$ & $\begin{array}{c}6.22 \\
(0.09)\end{array}$ \\
\hline $\mathrm{MgNi}_{4} \mathrm{~B}_{2}$ & 1 & 7.83 & 8.73 & 84.1 & 100.7 & 2 & 0.99 & 3.96 & 6.95 \\
\hline
\end{tabular}

* All measurements by electron probe microanalysis; ${ }^{* *} \mathrm{bdl}=$ below detection limit, ${ }^{+}$number of point analyses. 
Figure $9 \mathrm{a}, \mathrm{b}$ show secondary electron images of polished reaction product from Run 5 . In these examples, the core region appears as an elevated mound which in one case is intact, while in the other (Figure $9 \mathrm{~b}$ ), part of the core region is removed. Figure $9 \mathrm{c}, \mathrm{d}$ are backscattered electron images of the sample from Run 5. The Mg-Ni-B shell with Ni-B core structure is evident for this sample after a reaction time of $40 \mathrm{~h}$. The backscattered electron image in Figure $9 \mathrm{~d}$ again shows a core region that is removed from the $\mathrm{Mg}-\mathrm{Ni}-\mathrm{B}$ aggregate, presumably via the sample polishing step.

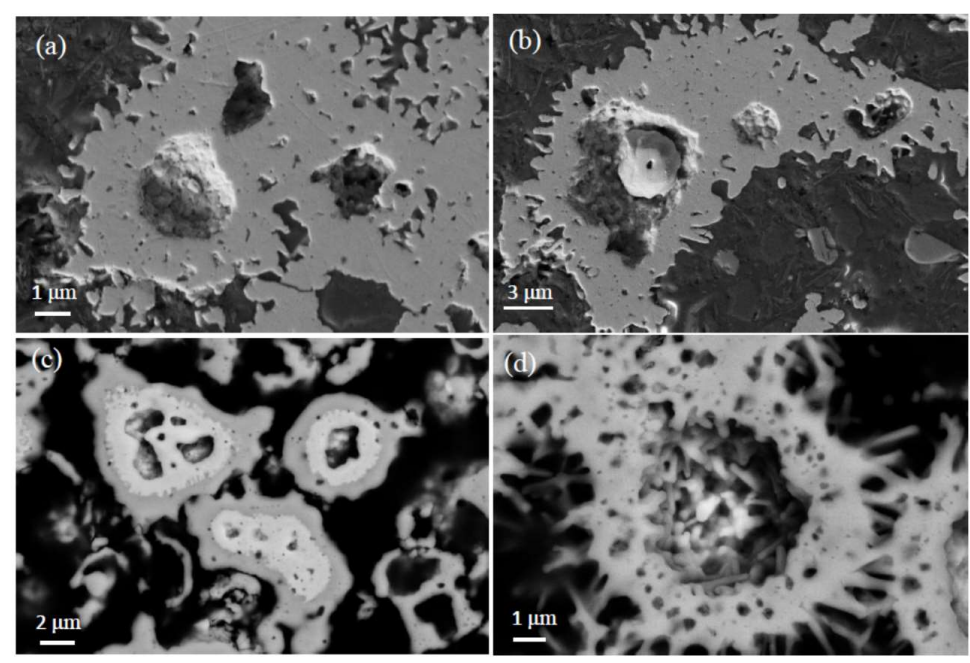

Figure 9. SEM image of the polished surface of reaction products from Run 5. In (a) a mound is apparent at the core part of the sample, while in (b) the mound shows a region in which material appears to have been removed. (c) Backscattered electron image shows the structure of a Ni-B core region surrounded by a $\mathrm{MgNi}_{3} \mathrm{~B}_{2}$ rim. (d) Backscattered electron image of $\mathrm{Mg}-\mathrm{Ni}-\mathrm{B}$ particle showing core region that is presumably removed through sample preparation.

Figure 10a shows a magnetic hysteresis loop at $290 \mathrm{~K}$ measured over a $\pm 5 \mathrm{~T}$ field for product from Run 4 . The magnetization increases with increasing magnetic field and then saturates at $0.2 \mathrm{~T}$ with a saturation value of $0.45 \mathrm{emu} / \mathrm{g}$. Figure $10 \mathrm{~b}$ shows the relatively narrow hysteresis loop with a coercivity field of 250 Oe.
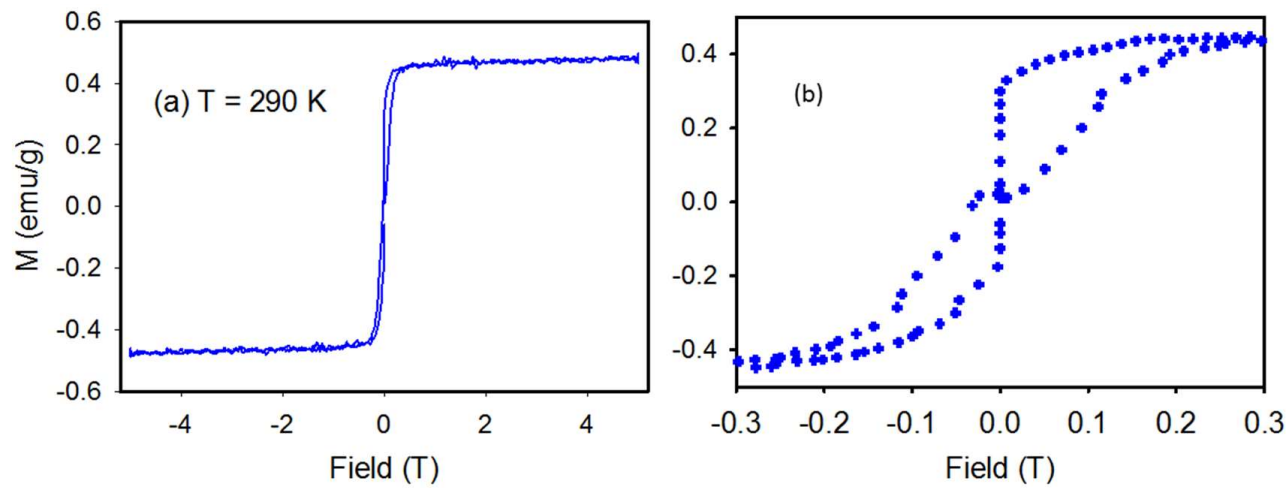

Figure 10. Magnetic data for Run 4 sample showing (a) Field dependant magnetization at $290 \mathrm{~K}$. (b) Higher magnification view of magnetization at low field.

\section{Discussion}

Interest in $\mathrm{Mg}-\mathrm{Ni}$ and $\mathrm{Mg}-\mathrm{Ni}-\mathrm{B}$ compounds is predominantly associated with their potential for use in Ni-metal hydride batteries [26,27] and for hydrogen storage [28,29]. In this latter instance, addition of $\mathrm{MgNi}_{3} \mathrm{~B}_{2}$ to a metal hydride system (e.g., $\mathrm{LiBH}_{4}-\mathrm{MgH}_{2}$ ) provides a catalytic effect that 
increases hydrogen storage by $\sim 9 \%$ [28]. Further work [29,30] shows that addition of Ni-B to the same system also enables growth of $\mathrm{MgNi}_{3} \mathrm{~B}_{2}$ in the dehydriding process. Thus, while $\mathrm{MgNi}_{3} \mathrm{~B}_{2}$ appears to be an ineffective material for hydrogen storage per se [14], the phase may be important in the evolution of effective hydrogen storage technology. Other compositions within the Mg-Ni-B phase space are also of interest, in particular $\mathrm{MgNi}_{7} \mathrm{~B}_{3}$ [4] and a new ternary diboride suite with compositions $\mathrm{Mg}_{3+\mathrm{x}} \mathrm{Ni}_{7-\mathrm{x}} \mathrm{B}_{2}$ [31]. This new diboride suite is also amenable to metal doping with consequent influence on magnetic properties [31]. In this discussion, we focus on $\mathrm{MgNi}_{3} \mathrm{~B}_{2}$ and other compounds formed under autogenous pressure conditions.

\subsection{Synthesis of $\mathrm{MgNi}_{3} \mathrm{~B}_{2}$}

In earlier work, we described an approach to synthesise $\mathrm{MgB}_{2}$ using autogenous pressure generated by the decomposition of $\mathrm{NaBH}_{4}$ or $\mathrm{KBH}_{4}[17,18]$ in the same type of reactor as in this study. In this earlier work we inferred, on the basis of pressure-temperature data [18], that in the presence of $\mathrm{Mg}, \mathrm{NaBH}_{4}$ begins to decompose at $\sim 80{ }^{\circ} \mathrm{C}-120{ }^{\circ} \mathrm{C}$ resulting in the formation of $\mathrm{H}_{2}(\mathrm{~g})$ and $\mathrm{B}_{2} \mathrm{H}_{6}(\mathrm{~g})$ and higher order borohydrides as noted by earlier researchers $[19,32]$. We also inferred higher temperature gas-solid reactions in this type of reactor under a range of conditions $[17,18]$. In these earlier studies, we used the thermocouple reading at the centre of the reactor to estimate the temperatures of these reactions. In this work, we have recalibrated the reactor to provide an estimate of the temperature experienced by the starting materials at the base of the reactor, in particular, at the hold temperatures used in all experiments and using the same ramp rates.

Puszkiel and Gennari note that alkali metal borohydrides do not desorb hydrogen below $\sim 400{ }^{\circ} \mathrm{C}$ [30]. However, our earlier work $[17,18]$ and analyses of gases produced during the reactions shown in Table 1 suggest otherwise. Accordingly, our analyses of gases sampled when the reactor thermocouple readings are $65{ }^{\circ} \mathrm{C}$ and $120{ }^{\circ} \mathrm{C}$ show the presence of $\mathrm{H}_{2}$ at $5 \%$ and $15 \%$ content, respectively. Our calibration of the thermocouple reading with the measured temperature at the base of the reactor suggests that $\mathrm{NaBH}_{4}$ experiences maximum temperatures between $120{ }^{\circ} \mathrm{C}$ and $200{ }^{\circ} \mathrm{C}$, respectively, at each of these gas sampling points. Thus, with no other source for $\mathrm{H}_{2}$ gas, we conclude that this is derived from the initial production of $\mathrm{B}_{2} \mathrm{H}_{6}$ via catalytic decomposition of $\mathrm{NaBH}_{4}[19,32]$.

As a further check on gas composition, $\mathrm{NO}_{2}$ gas concentrations are measured at $0.03 \mathrm{ppm}$ and $0.05 \mathrm{ppm}$ while $\mathrm{CO}_{2}$ is $83 \mathrm{ppm}$ and $127 \mathrm{ppm}$ for the $120^{\circ} \mathrm{C}$ and $200{ }^{\circ} \mathrm{C}$ samples, respectively. Methane is measured at $3.83 \%$ and $1.97 \%$ for the $120{ }^{\circ} \mathrm{C}$ and $200{ }^{\circ} \mathrm{C}$ samples, respectively. For gas analyses in this work, an additional signal shows a mass number equivalent to $\mathrm{B}_{2} \mathrm{H}_{6}$ is also present. This mass number may be equivalent to $\mathrm{O}_{2}$ albeit under all conditions the opportunity for gas leakage into or out of the sample container is minimal, as indicated by the $\mathrm{NO}_{2}$ and $\mathrm{CO}_{2}$ gas concentrations. Nevertheless, our analytical tools are not explicitly benchmarked against a standard $\mathrm{B}_{2} \mathrm{H}_{6}$ aliquot. Hence, we infer that $\mathrm{B}_{2} \mathrm{H}_{6}$ is also present in the reactor due to the catalytic decomposition of $\mathrm{NaBH}_{4}$.

The increase in pressure up to and including $\mathrm{T} \sim 420^{\circ} \mathrm{C}$ as shown in Figure 2 is primarily due to the evolution of $\mathrm{H}_{2}$ and $\mathrm{B}_{2} \mathrm{H}_{6}$ and the formation of higher borohydrides [17]. Figure 3 shows an increase in reactor pressure as the thermocouple reading increases up to $420{ }^{\circ} \mathrm{C}$ at which the ramp rate is held for $20 \mathrm{~min}$. With continued heating, the pressure decreases slightly due to the formation of higher order diborane species [33] or hydrides such as $\mathrm{MgH}_{2}$ [4,34]. $\mathrm{MgH}_{2}$ nanofibres form via reaction with $\mathrm{Mg}$ and $\mathrm{H}_{2}$ gas at a pressure of $1 \mathrm{MPa}$ to $2.5 \mathrm{MPa}$ in the range $420^{\circ} \mathrm{C}<\mathrm{T}<725^{\circ} \mathrm{C}$ [34] and also form under similar autogenous pressure conditions with the reaction between $\mathrm{Mg}$ and $\mathrm{NaBH}_{4}$ [18]. Decomposition of $\mathrm{NaBH}_{4}$ is accelerated in the presence of $\mathrm{Ni}$ and $\mathrm{Mg}$ as well as by intermediate phases such as $\mathrm{MgH}_{2}[18,35]$. The hydride, $\mathrm{Mg}_{2} \mathrm{NiH}_{4}$, also forms via the mechanical milling reaction of $\mathrm{MgH}_{2}$ with $\mathrm{Ni}$ at temperatures $>400{ }^{\circ} \mathrm{C}$ and pressures $>8 \mathrm{MPa}[36,37]$. As noted in earlier work, formation of $\mathrm{MgH}_{2}$ is a likely intermediate step during heating of the reactor to $>420{ }^{\circ} \mathrm{C} \mathrm{[18]}$. This intermediate phase enables formation of other $\mathrm{Mg}-\mathrm{Ni}, \mathrm{Mg}-\mathrm{B}, \mathrm{Ni}-\mathrm{B}$, and $\mathrm{Mg}-\mathrm{Ni}-\mathrm{B}$ compounds at higher temperatures [17]. 
In this process, a range of competing reactions-both solid-liquid, solid-gas, and liquid-gas-occur as the temperature is increased to $\mathrm{T}_{\max }$. At $\sim 420^{\circ} \mathrm{C}$, the formation of $\mathrm{MgH}_{2}$ and further decomposition of $\mathrm{NaBH}_{4}$ and higher order diboranes occurs [18]. In addition, as $\mathrm{T}>500^{\circ} \mathrm{C}$ other intermediate phases such as $\mathrm{Mg}\left(\mathrm{BH}_{4}\right)_{2}, \mathrm{NaMgH}_{3}$, and $\mathrm{MgB}_{2}$ are likely to form [17]. We have also explored the reactions of $\mathrm{Ni}$ metal with $\mathrm{NaBH}_{4}$ under similar conditions and note that Ni-B compounds form at autogenous pressures ranging between $1 \mathrm{MPa}$ and $2 \mathrm{MPa}$ and thermocouple temperatures of $500^{\circ} \mathrm{C}<\mathrm{T}<725^{\circ} \mathrm{C}$ (unpublished data). At these higher temperatures in the presence of $\mathrm{H}_{2}$ and borohydride gasses, we suggest that $\mathrm{Mg}-\mathrm{Ni}$ hydrides and $\mathrm{Mg}-\mathrm{Ni}$ borides form. Other likely phases include alkali metal composites similar to that described by Shao et al. [29] which include $\mathrm{LiH}-\mathrm{MgB}_{2}$ with Ni-B particles. The work by Shao et al. [29] shows that $\mathrm{MgNi}_{3} \mathrm{~B}_{2}$ forms as hydrogen is removed from the composite at $400{ }^{\circ} \mathrm{C}$. For the reactions described here, we suggest that a $\mathrm{NaH}-\mathrm{MgB}_{2}$ composite with $\mathrm{Ni}-\mathrm{B}$ forms, and enhances the production of $\mathrm{MgNi}_{3} \mathrm{~B}_{2}$.

With the increase in temperature to $T_{\max }$, and a hold for specific periods of time, vapour phase transfer of elements and compounds is accelerated and also results in condensation of some compounds and elements at the cooler top of the reactor [18]. For example, loss of $\mathrm{H}_{2}$ from the immediate vicinity of the reactants can occur through volatilisation of $\mathrm{NaH}$ and/or $\mathrm{Na}$ as well as residual $\mathrm{MgH}_{2}$ that subsequently condenses at the top of the reaction chamber $[17,18]$. At these higher reactor temperatures (i.e., $>500{ }^{\circ} \mathrm{C}$ ), the presence of $\mathrm{Na}$ as a liquid or as a gas is likely [18]. In addition, the decomposition of $\mathrm{NaBH}_{4}$ is accelerated in the presence of $\mathrm{MgH}_{2}$ [38]. Further complexity arises because, between $500^{\circ} \mathrm{C}$ and $600{ }^{\circ} \mathrm{C}, \mathrm{Mg}\left(\mathrm{BH}_{4}\right)_{2}$ decomposes to form $\mathrm{MgH}_{2}[17,39]$. Our analysis of $\mathrm{MgB}_{2}$ formation using an autogenous pressure reaction between $\mathrm{Mg}$ and $\mathrm{NaBH}_{4}$ shows that $\mathrm{Na}$ is poorly soluble in the diboride structure and thus, is not detected in the final product [17]. Under these reactor conditions where the base may reach up to $650{ }^{\circ} \mathrm{C}$ [18], $\mathrm{Na}$ is most commonly observed in phases at the cooler top of the reactor. EPMA data for $\mathrm{MgNi}_{3} \mathrm{~B}_{2}$ produced in this work suggests that $\mathrm{Na}$ is also not soluble in the predominant product.

Thus, reactions involving solid-gas and liquid-gas interactions compete at higher temperatures as illustrated by the change in reactor pressure(s) shown in Figure $2 \mathrm{~b}$. As new stable phases form, the autogenous pressure in the reactor changes over time (Figure $2 b$ ). In general, we interpret that gas phase reactions are near complete if the autogenous pressure is low (i.e., $<0.1 \mathrm{MPa}$ ) when the reactor is cooled from $T_{\max }$ (e.g., Run 3 of Figure $2 b$ ). Given the complexity of these intermediate reactions, the formation of $\mathrm{MgNi}_{3} \mathrm{~B}_{2}$ is nevertheless governed by generic conditions such as availability of elements (e.g., $\mathrm{Mg}$, Ni and B) in appropriate ratios (or compounds) and the temperature and pressure of reactions. We suggest that the overall reaction for formation of $\mathrm{MgNi}_{3} \mathrm{~B}_{2}$ in this system is:

$$
\mathrm{Mg}+3 \mathrm{Ni}+2 \mathrm{NaBH}_{4}=\mathrm{MgNi}_{3} \mathrm{~B}_{2}+2 \mathrm{NaH}+3 \mathrm{H}_{2}
$$

The additional products in Equation (1)-NaH and $\mathrm{H}_{2}$-are both gas phase at $\mathrm{T}_{\max }$. Hence, it is reasonable to assume that microstructures for $\mathrm{MgNi}_{3} \mathrm{~B}_{2}$ are moderated by solid-gas, liquid-gas, and possibly, vapour-liquid-solid mechanisms.

As noted in Table 1 and shown in Figure 4, other Mg-Ni phases occur in minor amounts as part of this synthesis method. For example, $\mathrm{MgNi}_{7} \mathrm{~B}_{3}$ and $\mathrm{MgNi}_{6.7} \mathrm{~B}_{2}$ occur as minor products in all experiments shown in Table 1. We also explored this method to produce, for example, $\mathrm{MgNi}_{7} \mathrm{~B}_{3}$ in higher yields under similar conditions with appropriate adjustment for molar ratios of starting materials. A maximum yield of $\sim 40 \%$ for $\mathrm{MgNi}_{7} \mathrm{~B}_{3}$ is obtained at $\mathrm{T}_{\max }=450{ }^{\circ} \mathrm{C}$ at the thermocouple and $\sim 4 \mathrm{MPa}$ pressure for $8 \mathrm{~h}$. Optimum yields occur when $\mathrm{Mg}$ is in excess by $20-30 \%$, consistent with the practice noted by Liao et al. [4].

\subsection{Microstructures}

SEM images of powders formed by this process show aggregates containing many nanometre-scale grains with a range of morphologies (Figure 5). A first impression from Figure 5 and the XRD data 
suggests that the aggregates are comprised of a single phase Mg-Ni-B compound with grains of varying size and shape. However, the microstructures revealed by polished sections provide observations that hint at a different interpretation and at key steps in the formation of $\mathrm{MgNi}_{3} \mathrm{~B}_{2}$ aggregates by this synthesis method.

For example, the centres of most aggregates contain a $\mathrm{Ni}$-boride phase such as $\mathrm{Ni}_{2} \mathrm{~B}$ or $\mathrm{Ni}_{3} \mathrm{~B}$ as shown in Table 3 and Figures 7-9. The higher boron content $\mathrm{Ni}_{4} \mathrm{~B}_{3}$ is also present and usually a phase that lies between the $\mathrm{Ni}$-rich core and the $\mathrm{MgNi}_{3} \mathrm{~B}_{2}$ outer regions of an aggregate. This morphology suggests that Ni-rich phases formed first in this process presumably via the interaction of $\mathrm{H}_{2}(\mathrm{~g})$ and $\mathrm{B}_{2} \mathrm{H}_{6}$ (g) with $\mathrm{Ni}$ metal at $\mathrm{T} \leq 420{ }^{\circ} \mathrm{C}$. The autogenous pressure at low temperatures in the reactor is insufficient to ensure $\mathrm{H}_{2}$ diffusion into bulk $\mathrm{Ni}$ albeit $\mathrm{H}_{2}$ may penetrate surface layers of individual grains to $\sim 30 \mu \mathrm{m}$ [40]. Thus, it is likely that Ni-borides form at lower temperatures through reaction with $\mathrm{B}_{2} \mathrm{H}_{6}$ and the higher order analogues as shown in Reactions (2) and (3)

$$
\begin{aligned}
& 4 \mathrm{Ni}+\mathrm{B}_{2} \mathrm{H}_{6}=2 \mathrm{Ni}_{2} \mathrm{~B}+3 \mathrm{H}_{2} \\
& 6 \mathrm{Ni}+\mathrm{B}_{2} \mathrm{H}_{6}=2 \mathrm{Ni}_{3} \mathrm{~B}+3 \mathrm{H}_{2}
\end{aligned}
$$

Above $420^{\circ} \mathrm{C}$, with formation of $\mathrm{MgH}_{2}$ and $\mathrm{Mg}\left(\mathrm{BH}_{4}\right)_{2}$, their subsequent decomposition [17,40], and the continued decomposition of $\mathrm{NaBH}_{4}$ [38], reactive $\mathrm{Mg}$ and $\mathrm{B}$ species may result that enhance formation of $\mathrm{Mg}-\mathrm{Ni}$ and $\mathrm{Mg}-\mathrm{Ni}-\mathrm{B}$ phases. $\mathrm{MgB}_{2}$ also forms above $350{ }^{\circ} \mathrm{C}$ under these autogenous pressure conditions [18] but is not evident in the final product due to formation of $\mathrm{MgNi}_{3} \mathrm{~B}_{2}[29,30]$.

For the experiments listed in Table 1, the evidence from XRD data does not correlate well with the notional abundance of the Ni-boride phases shown via polished section microscopy. We attribute the low estimated values for $\mathrm{Ni}$-boride phases using XRD Rietveld refinement to the modest signal/noise ratio, few reflections due to symmetry and overlap of key reflections for $\mathrm{MgNi}_{3} \mathrm{~B}_{2}$ and $\mathrm{MgNi}_{6.7} \mathrm{~B}_{2}$ [4,5] as well as with $\mathrm{Ni}_{2} \mathrm{~B}$ and $\mathrm{Ni}_{3} \mathrm{~B}$. This suggestion also implies that the relative proportions of phases in the products shown in Table 1 are not accurate and, we estimate, may be in error by as much as $10 \%$ relative. An intense X-ray beam (e.g., rotating anode; synchrotron) is required to provide higher accuracy of calculations for relative proportions of phases in these aggregates.

The relationships between the inner and outer parts of an aggregate are varied in detail. In general, the core region is a boron-poor Ni-boride with transition to boron-rich phases (e.g., $\mathrm{Ni}_{4} \mathrm{~B}_{3} ; \mathrm{MgNi}_{3} \mathrm{~B}_{2}$ ) towards the outer margin, or shell, of an aggregate. This general trend also supports the suggestion that Mg-rich phase(s) form after the Ni-borides through solid-gas and/or liquid-gas reactions. While we have no definitive evidence, the formation of $\mathrm{MgNi}_{3} \mathrm{~B}_{2}$ rods or needles (Figure $5 \mathrm{~b}$ ) may occur via a vapour-liquid-solid mechanism in this type of environment. The presence of "vacant" cores-or an empty shell morphology—suggests that in some cases, gases such as $\mathrm{H}_{2}$ are trapped within the aggregate. Through a change in reactor pressure (with change in temperature), the trapped gas exits the core of the aggregate. The gas is likely to be trapped during a rapid growth stage when the reactor temperature is increased to $\mathrm{T}_{\max }$.

The consistent composition of the aggregate shell region as demonstrated by EPMA analyses in Table 3 is noteworthy. Nevertheless, two sets of spot analyses in Table 3 show that other Mg-Ni-B phases may co-exist and deserve further attention. These analyses are for aggregates from Run 5 for which the $\mathrm{T}_{\text {max }}$ hold time is $40 \mathrm{~h}$. The inner region of one aggregate shows an average composition of $\mathrm{Mg}_{0.34} \mathrm{Ni}_{3.49} \mathrm{~B}$ (or $\sim \mathrm{MgNi}_{10} \mathrm{~B}_{3}$ ) which has not been observed previously $[4,5,31]$. The outer regions of an aggregate also from Run 5 shows a composition—at one location only-of $\mathrm{MgNi}_{4} \mathrm{~B}_{2}$. These compositions are significantly different to the notional stoichiometry of the starting materials. With different reactor conditions (e.g., longer reaction times, higher proportion of $\mathrm{Ni}$ and $\mathrm{B}$ in starting materials), new forms of Mg-Ni-B phases such as those implied by the EPMA data in Table 3 may be obtained. 


\subsection{Magnetic Properties}

Manfrinetti et al. [5] present magnetic properties of polycrystalline $\mathrm{MgNi}_{3} \mathrm{~B}_{2}$ with an applied field of 0.7 Tesla. At room temperature, $\mathrm{MgNi}_{3} \mathrm{~B}_{2}$ is diamagnetic [5] consistent with filled Ni-3d bands and $\mathrm{MgNi}_{3} \mathrm{~B}_{2}$ becomes positive at $\sim 165 \mathrm{~K}$. In contrast, the sample from Run 4 of this study shows substantially different magnetic behaviour. Figure 10a shows a magnetic hysteresis loop at $290 \mathrm{~K}$ for Run 4 where magnetization increases with increasing magnetic field and then saturates at $0.2 \mathrm{~T}$ with a saturation value of $0.45 \mathrm{emu} / \mathrm{g}$. The relatively narrow hysteresis loop with a coercivity field of 250 Oe may be due to the presence of a ferromagnetic impurity such as elemental nickel. This distinctly different magnetic signature of multi-phase $\mathrm{MgNi}_{3} \mathrm{~B}_{2}$ aggregates produced by autogenous pressure synthesis is clearly influenced by the core-shell nature of the product in which a Ni-boride core is encompassed by nano-scale $\mathrm{MgNi}_{3} \mathrm{~B}_{2}$ rods or particles.

\section{Conclusions}

In summary, the ternary intermetallic $\mathrm{MgNi}_{3} \mathrm{~B}_{2}$ as aggregates in conjunction with Ni-boride phases have been synthesized using autogenous pressure by the reaction of $\mathrm{NaBH}_{4}, \mathrm{Mg}$, and Ni powder. XRD analysis of the primary product is consistent with previous single crystal and powder diffraction studies of $\mathrm{MgNi}_{3} \mathrm{~B}_{2}$ by Manfrinetti et al [5]. However, microanalyses of polished sections show that these micrometer scale aggregates contain inner cores of Ni-boride phases such as $\mathrm{Ni}_{2} \mathrm{~B}$ and $\mathrm{Ni}_{3} \mathrm{~B}$ surrounded by successively more boron-rich phases such as $\mathrm{Ni}_{4} \mathrm{~B}_{3}$ and $\mathrm{MgNi}_{3} \mathrm{~B}_{2}$. In this synthesis method, solid-gas and liquid-gas reactions are dominant formation mechanisms for intermediate phases and final products. The microstructures also indicate that Ni-borides form at lower temperature than $\mathrm{MgNi}_{3} \mathrm{~B}_{2}$ in this process. EPMA data provide circumstantial evidence for other $\mathrm{Mg}-\mathrm{Ni}-\mathrm{B}$ phases such as $\mathrm{MgNi}_{10.5} \mathrm{~B}_{3}$, and possibly, $\mathrm{MgNi}_{4} \mathrm{~B}_{2}$. These core-shell structures of Ni-boride $/ \mathrm{MgNi}_{3} \mathrm{~B}_{2}$ aggregates demonstrate substantially different magnetic properties to stoichiometric $\mathrm{MgNi}_{3} \mathrm{~B}_{2}$ that is synthesized only at higher temperatures and longer time intervals [5].

Acknowledgments: This research did not receive any specific grant from funding agencies in the public, commercial, or not-for-profit sectors. Access to, and ongoing assistance from, QUT's Central Analytical Research Facility (CARF) administered by the Institute for Future Environments is gratefully acknowledged. In particular, advice on techniques and support from Jamie Riches, Henry Spratt, Natalia Danilova, Rene Diocares, and Pamela Limpin, as well as polished samples preparation by Chris West and Don McAuley are especially appreciated.

Author Contributions: Ian D. R. Mackinnon, Mahboobeh Shahbazi and Henrietta E. Cathey conceived and designed the experiments; Mahboobeh Shahbazi and Henrietta E. Cathey performed the experiments; Ian D. R. Mackinnon, Mahboobeh Shahbazi and Henrietta E. Cathey analyzed the data; Ian D. R. Mackinnon, Shahbazi and Henrietta E. Cathey wrote the paper.

Conflicts of Interest: The authors declare no conflict of interest.

\section{References}

1. Zhang, J.; Zhu, Y.; Wang, Y.; Pu, Z.; Li, L. Electrochemical hydrogen storage properties of $\mathrm{Mg}_{2-\mathrm{x}} \mathrm{Al}_{\mathrm{x}} \mathrm{Ni}$ $(x=0,0.3,0.5,0.7)$ prepared by hydriding combustion synthesis and mechanical milling. International. Int. J. Hydrog. Energy 2012, 37, 18140-18147. [CrossRef]

2. Cova, F.; Larochette, P.A.; Gennari, F. Hydrogen sorption in $\mathrm{MgH}_{2}$-based composites: The role of $\mathrm{Ni}$ and $\mathrm{LiBH}_{4}$ additives. Int. J. Hydrog. Energy 2012, 37, 15210-15219. [CrossRef]

3. Shao, H.; Asano, K.; Enoki, H.; Akiba, E. Fabrication and hydrogen storage property study of nanostructured Mg-Ni-B ternary alloys. J. Alloys Compd. 2009, 479, 409-413. [CrossRef]

4. Liao, C.Z.; Dong, C.; Zeng, L.M.; He, B.; Cao, W.H.; Yang, L.H. Crystal structure and physical properties of the new ternary compound $\mathrm{MgNi}_{7} \mathrm{~B}_{3}$. J. Alloys Compd. 2010, 493, 31-34. [CrossRef]

5. Manfrinetti, P.; Pani, M.; Dhar, S.K.; Kulkarni, R. Structure, transport and magnetic properties of $\mathrm{MgNi}_{3} \mathrm{~B}_{2}$. J. Alloys Compd. 2007, 428, 94-98. [CrossRef]

6. Pedneault, S.; Huot, J.; Rouéa, L. Nanostructured $\mathrm{Mg}_{2} \mathrm{Ni}$ materials prepared by cold rolling and used as negative electrode for Ni-MH batteries. J. Power Sources 2008, 185, 566-569. [CrossRef] 
7. Aswal, D.K.; Shashwati, S.; Singh, A.; Chandrasekhar Rao, T.V.; Vyas, J.C.; Gupta, L.C.; Gupta, S.K.; Sahni, V.C. Synthesis and characterization of $\mathrm{MgB}_{2}$ superconductor. Phys. C Supercond. 2001, 363, 149-154. [CrossRef]

8. Takano, Y.; Oguro, N.; Kaieda, Y.; Togano, K. Superconducting properties of combustion synthesized $\mathrm{MgB}_{2}$. Phys. C Supercond. 2004, 412, 125-129. [CrossRef]

9. Portehault, D.; Devi, S.; Beaunier, P.; Gervais, C.; Giordano, C.; Sanchez, C.; Antonietti, M. A general solution route toward metal boride nanocrystals. Angew. Chem. Int. Ed. 2011, 50, 3262-3265. [CrossRef] [PubMed]

10. Carenco, S.; Portehault, D.; Boissière, C.; Mézailles, N.; Sanchez, C. Nanoscaled metal borides and phosphides: Recent developments and perspectives. Chem. Rev. 2013, 113, 7981-8065. [CrossRef] [PubMed]

11. Li, W.; Vajo, J.J.; Cumberland, R.W.; Liu, P.; Hwang, S.J.; Kim, C.; Bowman, R.C. Hydrogenation of magnesium nickel boride for reversible hydrogen storage. Phys. Chem. Lett. 2010, 1, 69. [CrossRef]

12. Grasso, G.; Malagoli, A.; Modica, M.; Tumino, A.; Ferdeghini, C.; Siri, A.S.; Vignola, C.; Martini, L.; Previtali, V.; Volpini, G. Fabrication and properties of monofilamentary $\mathrm{MgB}_{2}$ superconducting tapes. Supercond. Sci. Technol. 2003, 16, 271. [CrossRef]

13. Bellingeri, E.; Malagoli, A.; Modica, M.; Braccini, V.; Siri, A.S.; Grasso, G. Neutron scattering studies of superconducting $\mathrm{MgB}_{2}$ tapes. Supercond. Sci. Technol. 2003, 16, 276-280. [CrossRef]

14. Gross, K.J.; Zuttel, A.; Schlapbach, L. On the possibility of metal hydride formation Part I. The synthesis of MgNi B by mechanical milling and sintering. J. Alloys Compd. 1998, 274, 234. [CrossRef]

15. Jung, W. Preparation and crystal structure of $\mathrm{MgNi}_{3} \mathrm{~B}_{2}$ and $\mathrm{Li}_{1.2} \mathrm{Ni}_{2.5} \mathrm{~B}_{2}$. Z. Naturforsch. 1977, $32,1371$. [CrossRef]

16. Vajeeston, P.; Ravindran, P.; Ravi, C.; Asokamani, R. Electronic structure, bonding, and ground-state properties of $\mathrm{AlB}_{2}$-type transition-metal diborides. Phys. Rev. B 2001, 63, 045115. [CrossRef]

17. Mackinnon, I.D.R.; Shahbazi, M.; Alarco, J.A.; Talbot, P.C. Low temperature decomposition of metal borohydride drives autogenous synthesis of $\mathrm{MgB}_{2}$. Supercond. Sci. Technol. 2017, 30, 055004. [CrossRef]

18. Mackinnon, I.D.R.; Winnett, A.; Alarco, J.A.; Talbot, P.C. Synthesis of $\mathrm{MgB}_{2}$ at low temperature and autogenous pressure. Materials 2014, 7, 3901-3918. [CrossRef] [PubMed]

19. Clarke, R.P.; Pease, R.N. A preliminary study of the kinetics of pyrolysis of Diborane. J. Am. Chem. Soc. 1951, 73, 2132-2134. [CrossRef]

20. McCusker, L.B.; Von Dreele, R.B.; Cox, D.E.; Louer, D.; Scardi, P. Rietveld refinement guidelines. J. Appl. Crystallogr. 1999, 32, 36-50. [CrossRef]

21. Momma, K.; Izumi, F. VESTA 3 for three-dimensional visualization of crystal, volumetric and morphology data. J. Appl. Crystallogr. 2011, 44, 1272-1276. [CrossRef]

22. Bastin, G.F.; Heijligers, H.J.M. Quantitative electron probe microanalysis of Boron. J. Solid State Chem. 2000, 154, 177-187. [CrossRef]

23. Bastin, G.F.; Dijkstra, J.M.; Heijligers, H.J.M. PROZA96: An improved matrix correction program for electron probe microanalysis, based on a double gaussian phi(rho z) approach. X-Ray Spectrom. 1998, 27, 3-10. [CrossRef]

24. Drouin, D.; Couture, A.R.; Joly, D.; Tastet, X.; Aimez, V.; Gauvin, R. CASINO V2. 42-A fast and and easy-to-use modeling tool for scanning electron microscopy and microanalysis users. Scanning 2007, 29, 92-101. [CrossRef] [PubMed]

25. Goldstein, J. Scanning Electron Microscopy and X-ray Microanalysis, Kluwer Academic, Plenum Publishers; Springer: New York, NY, USA, 2003.

26. Rongeat, C.; Grosjean, M.-H.; Ruggeri, S.; Dehmas, M.; Bourlot, S.; Marcotte, S.; Rou'e, L. Evaluation of different approaches for improving the cycle life of $\mathrm{MgNi}$-based electrodes for $\mathrm{Ni}-\mathrm{MH}$ batteries. J. Power Sources 2006, 158, 747-753. [CrossRef]

27. Varin, R.A.; Czujko, T.; Wronski, Z.S. Nanomaterials for Solid State Hydrogen Storage; Springer: New York, NY, USA, 2009.

28. Shao, J.; Xiao, X.; Chen, L.; Fan, X.; Li, S.; Ge, H.; Wang, Q. Enhanced hydriding-Dehydriding performance of $2 \mathrm{LiBH}_{4}-\mathrm{MgH}_{2}$ composite by the catalytic effects of transition metal chlorides. J. Mater. Chem. 2012, 22, 20764-20772. [CrossRef]

29. Shao, J.; Xiao, X.; Chen, L.; Fan, X.; Han, L.; Li, S.; Ge, H.; Wang, Q. Enhanced hydriding-Dehydriding performance of a $2 \mathrm{LiH}-\mathrm{MgB}_{2}$ composite by the catalytic effects of $\mathrm{Ni}-\mathrm{B}$ nanoparticles. J. Mater. Chem. A 2013, 1, 10184-10192. [CrossRef] 
30. Puszkiel, J.A.; Gennari, F.C. Reversible hydrogen storage in metal-doped $\mathrm{Mg}-\mathrm{LiBH}_{4}$ composites. Scripta Mater. 2009, 60, 667-670. [CrossRef]

31. Liao, C.-Z.; Dong, C.; Shih, K.; Zeng, L.; He, B.; Cao, W.; Yang, L. Preparation and properties of a new ternary phase $\mathrm{Mg}_{3+\mathrm{x}} \mathrm{Ni}_{7-\mathrm{x}} \mathrm{B}_{2}(0.17-0.66)$ and its Cu-doping effect. J. Solid State Chem. 2015, 226, 24-28. [CrossRef]

32. Bragg, J.K.; McCarthy, L.V.; Norton, F.J. Kinetics of Pyrolysis of Diborane. J. Am. Chem. Soc. 1951, 73, 2134-2140. [CrossRef]

33. Borer, K.; Littlewood, A.B.; Phillips, C.S.G. A gas-chromatographic study of the diborane pyrolysis. J. Inorg. Nucl. Chem. 1960, 15, 316-319. [CrossRef]

34. Zhu, C.; Hayashi, H.; Saita, I.; Akiyama, T. Direct synthesis of $\mathrm{MgH}_{2}$ nanofibers at different hydrogen pressures. Int. J. Hydrog. Energy 2009, 34, 7283-7290. [CrossRef]

35. Sastri, M.V.; Viswanathan, B.; Murthy, S.S. Metal Hydrides-Fundamentals and Applications; Narosa Publishing House: New Delhi, India, 1998.

36. Varin, R.A.; Czujko, T.; Wasmund, E.B.; Wronski, Z.S. Catalytic effects of various forms of nickel on the synthesis rate and hydrogen desorption properties of nanocrystalline magnesium hydride $\left(\mathrm{MgH}_{2}\right)$ synthesized by controlled reactive mechanical milling (CRMM). J. Alloys Compd. 2007, 432, 217-231. [CrossRef]

37. Polanski, M.; Nielsen, T.K.; Kunce, I.; Norek, M.; Płocinski, T.; Jaroszewicz, L.R.; Gundlach, C.; Jensen, T.R.; Bystrzycki, J. $\mathrm{Mg}_{2} \mathrm{NiH}_{4}$ synthesis and decomposition reactions. Intnl. J. Hydrog. Energy 2013, 38, 4003-4010. [CrossRef]

38. Czujko, T.; Varin, R.A.; Wronski, Z.; Zaranski, Z.; Durejko, T. Synthesis and hydrogen desorption properties of nanocomposite magnesium hydride with sodium borohydride $\left(\mathrm{MgH}_{2}+\mathrm{NaBH}_{4}\right)$. J. Alloys Compd. 2007, 427, 291-299. [CrossRef]

39. Prikhna, T.A.; Gawalek, W.; Savchuk, Y.M.; Moshchil, V.E.; Sergienko, N.V.; Surzhenko, A.B.; Wendt, M.; Dub, S.N.; Melnikov, V.S.; Schmidt, C.; et al. High-pressure synthesis of a bulk superconductive MgB2-based material. Phys. C Supercond. 2003, 386, 565-568. [CrossRef]

40. Baranowski, B.; Filipek, S.M. 45 Years of nickel hydride-History and perspectives. J. Alloys Compd. 2005, 404, 2-6. [CrossRef] 